\title{
Parliament, Sovereignty and the Paradox of the Political Constitution
}

\author{
Chris McCorkindale*
}

\section{INTRODUCTION}

Keith Ewing has made an outstanding - indeed, an inspiring - contribution to the way in which we perceive and understand the United Kingdom's (still) ${ }^{1}$ political constitution, both in theory ${ }^{2}$ and in practice. ${ }^{3}$ In this chapter, however, I will take as my point of departure what in my view is a tension between two claims that he has made about that tradition. The first is made in defence of Parliamentary sovereignty, which for Ewing is the 'core legal principle of the political constitution,' and this, he says, for two reasons. First, because it defines the power of the legislature itself, having evolved to become 'no more and no less than the legal principle underpinning the political principle that there should be no legal limit to the wishes of the people. ${ }^{4}$ Second, because Parliament, in the exercise of its legislative function, delineates the proper scope of lawful executive action. Seen in this light, Ewing defends judicial review on traditional ultra vires grounds as being 'not so much a usurpation of the sovereignty of Parliament as its vindication, to the extent that the courts do not permit Ministers or others to stray beyond their Parliamentary mandate. ${ }^{5}$ For Ewing, the problem of judicial review (against which so much of modern political constitutionalism has been defined) ${ }^{6}$ emerges where judicial activism has gone further than this in order to wash through (and by implication to constrain) progressive social and economic legislation and government action with conservative common law values. ${ }^{7}$ For these reasons, Ewing found it frustrating that JAG Griffith, in his seminal 1978 Chorley Lecture, The Political Constitution, ${ }^{8}$ paid such little attention to the principle of Parliamentary sovereignty, because Ewing found it difficult to see how a political constitution could operate without it..$^{9}$ Indeed, Griffith's only explicit reference to the principle in that lecture was to

\footnotetext{
* Senior Lecturer in Law, University of Strathclyde. Email: christopher.mccorkindale@strath.ac.uk.

${ }^{1}$ KD Ewing, 'The Resilience of the Political Constitution' (2013) 14(12) German Law Journal 2111.

${ }^{2}$ Ibid.

${ }^{3}$ See, for example, Ewing's prescriptions for the constitution of social democracy in 'Jeremy Corbyn and the Law of Democracy' (2017) 28(2) King's Law Journal 343.

${ }^{4}$ Ewing (n 1) 2118.

${ }^{5}$ Ibid.

${ }^{6}$ For a critique of this defensive posture see Marco Goldoni and Chris McCorkindale, 'Three Waves of Political Constitutionalism' (2019) 30(1) King's Law Journal 74.

${ }^{7}$ Ewing (n 1) 2118.

8 JAG Griffith, 'The Political Constitution' (1979) 42(1) Modern Law Review 1.

${ }^{9}$ Ewing (n 1).
} 
deny - contra contemporaneous challenges ${ }^{10}$ - that the sovereignty of Parliament was amongst the constitutional vices of the time. ${ }^{11}$

The second claim that Ewing makes for the political constitution is offered in a recent paper on the constitution of social democracy. There, Ewing (rightly) said that 'Keynsian economics needs different kinds of constitutional arrangements than neo-liberal economics,' observing wryly that 'the constitutional preconditions and priorities of Marx are different from those of Hayek. ${ }^{12}$ However, the reference here - to Marx's The Civil War in France ${ }^{13}$ - is telling. It was, after all, the reflections documented there about the experience of the Paris Commune that caused Marx to reconsider his view, expressed in The Communist Manifesto, that 'the first step in the revolution by the working class is to raise the proletariat to the position of ruling class to win the battle of democracy ${ }^{\prime}{ }^{14}$ that, in other words, the working class must win, and then put to use, the ready-made apparatus of the state, and in particular the legislature, to their ends. Instead, the experience of the Commune, 'when, for the first time, the proletariat held political power for a two-month period, ${ }^{, 15}$ taught Marx - and later editions of The Communist Manifesto were prefaced with this reflection - that the working class cannot rest content with taking possession of the existing machinery of the State in order to place it in the service of its own aims,' but that a radical reorganisation of political power would be required if that power was not to be abused once more against them. ${ }^{16}$

The tension, then, (at least as I see it) is that the former claim - that faith ought to be shown to the principle of Parliamentary sovereignty as a sine qua non of the political constitution - may well be the most significant restraint upon the radical potential of the latter. Put differently, the dynamic that has traditionally defined the political constitution has been two-fold. First, an attack against the effectiveness of Parliament as an institution, and against its legislative supremacy, from those conservative forces ${ }^{17}$ who have favoured stronger legal and judicial checks on the exercise of political

\footnotetext{
${ }^{10}$ Amongst the targets of Griffith's ire were Lord Hailsham's The Dilemma of Democracy: Diagnosis and Prescription (London, Collins, 1978) and Lord Scarman's English Law - The New Dimension (London, Stevens, 1974).

${ }^{11}$ Griffith (n 8) 18.

${ }^{12}$ Ewing (n 3) 343.

${ }^{13}$ Karl Marx, The Civil War in France (1870-171) (Moscow, Progress, 1948).

${ }^{14}$ Karl Marx and Friedrich Engels, The Communist Manifesto (1848) (New York, Modern Reader, 1968) 93.

${ }^{15}$ See Friedrich Engels, 'Preface to the English edition', in Karl Marx and Friedrich Engels, The Communist Manifesto (1888) (London, New York, Verso, 1998).

${ }^{16} \mathrm{lbid}$.

${ }^{17}$ As well as Hailsham and Scarman ( 10 ) political constitutionalists have reacted to the later work of, for example, Sir John Laws, 'Law and Democracy' [1995] Public Law 2 and TRS Allan's Law, Liberty and Justice: The Legal Foundations of British Constitutionalism (Oxford, Clarendon Press, 1993) and Constitutional Justice: A Liberal Theory of the Rule of Law (Oxford, OUP, 2001).
} 
power. Second, a response by political constitutionalists in defence of 'actually existing democracy'18 - a re-examination in defence of Parliament's record ${ }^{19}$ - that (precisely because the posture is a defensive one) leaves untouched the core assumptions (the sovereignty of Parliament foremost amongst them) that underpin the political constitution.

In this chapter I want to challenge political constitutionalism from a different angle. This is not a challenge from law: that the political constitution must be constrained by law in order to guard against the effects of political hyperactivity (that, as Lord Denning said, left unchecked the powers of the Welfare State lead to the Totalitarian State) ${ }^{20}$ Rather, this is a challenge from politics: that the core of the political constitution tends - indeed, tends by design - to undermine the potential of, and for, meaningful political action. Parliamentary sovereignty, this is to say, monopolises the public space because (understood in own terms) it is from there, through there and against there that the political legitimacy of all else either flows or is contingent. In order to embrace the potential of political action - action that, as Ewing has said, 'is not just about removing "them" but also,' and truly, 'about empowering "us"'21 - political constitutionalists (certainly political constitutionalists of the left) 22 must think beyond the unitary implications of sovereignty (whether Parliamentary or popular) and instead embrace those fundamental principles of constitutionalism which may constitute, maintain and augment the plurality of spaces from which that power might be generated, and which in the performance of that task carry their own legitimacy.

In support of this claim, let us return to a period of constitutional history that has been a rich source of thought for contemporary political constitutionalists: the constitutional tumults of $17^{\text {th }}$ century England. ${ }^{23}$ Through a detailed examination of King Charles I's demand for ship money - a form of extra-Parliamentary taxation levied on coastal towns by prerogative writ in order to maintain a naval fleet in times of war, that controversially was expanded inland by the King during peacetime -

\footnotetext{
${ }^{18}$ See Richard Bellamy, Political Constitutionalism: A Republican Defence of the Constitutionality of Democracy (Cambridge, CUP, 2007).

${ }^{19}$ See Adam Tomkins, 'In Defence of the Political Constitution' (2002) 22(1) OJLS 157 and Our Republican Constitution (Oxford and Portland, Oregon, Hart Publishing, 2005).

${ }^{20}$ Sir Alfred Denning, Freedom Under the Law (Hamlyn Lectures) (London, Stevens and Sons, 1949) 126.

${ }^{21}$ Ewing (n 1) 2117.

${ }^{22}$ Whilst in recent times political constitutionalism has most closely been associated with the political left, recent work by Graham Gee has sought to recover the link between political constitutionalism and the political right - see Graham Gee, 'The Political Constitution and the Political Rights' (2019) (30)(1) King's Law Journal 148.

${ }^{23}$ See, for example, Martin Loughlin, 'Constituent Power Subverted: From English Constitutional Argument to British Constitutional Practice' in Martin Loughlin and Neil Walker (eds), The Paradox of Constitutionalism: Constituent Power and Constitutional Form (Oxford, OUP, 2007) and Tomkins, Our Republican Constitution (n 19).
} 
and of the famous response made by Parliament's chief propagandist, Henry Parker, we will see that the case for Parliament's supremacy, as it emerged from (and asserted itself in) conflict with still prevailing claims of Royal absolutism, both invoked and immediately sought to contain that active and constitutive power of the people themselves. If the legacy of this double move has been (intentionally) to obscure that constituent power, in order to preserve a new order with Parliament's supremacy at its core, then what is at stake here in recognising and exposing that move is the opportunity once more to think radically about the virtues of politics and of the plurality of constitutional spaces within which those virtues might best be nurtured.

\section{THE DEMAND FOR SHIP MONEY}

The Crown's right to requisition both ships and men in time of emergency has long been accepted 'in the widest manner'. ${ }^{24}$ It was, however, '[t]he attempt made by Charles I to use his prerogative over ships and shipping to raise a permanent extra-Parliamentary revenue by means of ship-money' which roused the suspicions of his subjects. ${ }^{25}$ Having dissolved Parliament on March $2^{\text {nd }} 1629$, following a 'disorderly scene' in the Commons, when the Speaker, John Finch, had been forcibly held in his chair to receive a stinging remonstrance against the Crown's taking of tonnage and poundage without the consent of the Parliament, ${ }^{26}$ Charles would wait eleven years before calling another. In the meantime, however, the Crown's need to generate income was undiminished. ${ }^{27}$ By 1634 it was thought that England's fleet would struggle to keep up with its expanding and improving French and Dutch counterparts. Whilst the law would allow Charles to requisition private ships, however, it would not allow him the money to fit his own. As Glenn Burgess observed, '[the law] allowed [the king] to do what he did not need to do, but did not allow him to do what he needed to do.' ${ }^{28}$ To be sure, ship money of sorts was nothing new. As late as 1619 , James I had raised nearly $£ 50,000$ from seaport towns in lieu of ships for war against Algiers. ${ }^{29}$ In that case, the country was on a war footing and the danger to the Commonwealth was both immediate and visible. In 1634, however, Charles issued a

\footnotetext{
${ }^{24}$ W Holdsworth, 'The Power of the Crown to Requisition British Ships in a National Emergency' (1919) 35 Law Quarterly Review 12, 12-13. 25 Ibid 26.

${ }^{26}$ FW Maitland, The Constitutional History of England (Cambridge, Cambridge University Press, 1908) 314.

${ }^{27}$ On the contribution of the Crown's 'poverty' to the eventual outbreak of civil war see, generally, Glenn Burgess, The Causes of the English Civil War: The Ford Lectures Delivered in the University of Oxford 1987-1988 (Oxford, Clarendon Press, 1990) esp ch 7.

28 Ibid 183.

${ }^{29}$ R Tanner, English Constitutional Conflicts of the Seventeenth Century 1603-1689 (Cambridge, Cambridge University Press, 1928) 76.
} 
writ requisitioning ships, or money in lieu thereof, directly from his people against the widely held suspicion that no such threat was in fact imminent.

The writs of 1634, commonly attributed to the Attorney General, William Noy, were carefully drafted to conform to old precedents: restricted in application to the maritime counties and seaport towns and asking first for ships and not for money. ${ }^{30}$ The initial collection which followed was relatively successful, 79,589 pounds having been collected from assessments totalling 80,609 . However, having invested some 88,000 pounds on their fleet, the Crown required yet more income and so, by August 4 1635, a second levy was charged which not only renewed the previous maritime levy, but which extended the tax inwards, to the inland counties. ${ }^{31}$ '[T] his burden of defence ${ }^{32}$ which touches all,' the writ explained, 'ought to be borne by all. ${ }^{33}$ Accordingly, the writ was accompanied with an instruction to those sheriffs charged with collection to levy - instead of a ship - a specified sum of money. ${ }^{34}$

Charles had fully anticipated the unpopularity of the revised policy, and, anticipating the difficulties in collection which surely followed, sought to counteract his subjects' displeasure with the support of his judges. Thus, having already offered his support for the initial writs, the royalist judge, Finch, urged his colleagues to subscribe to an extra-judicial opinion maintaining the legality of the policy. This they did, to the effect that:

(1)...where the benefit of naval defence was more particularly felt by the coastal districts, they alone should contribute to the cost; (2) that the King was sole judge of whether the danger extended to the country as a whole; and (3) that where he judged that it did so, the burden of defence fell on all alike. ${ }^{35}$

To this (unpublished) opinion Hutton did not subscribe, and Croke offered a separate opinion. ${ }^{36}$ Frustrated by continued problems of collection, Charles returned for a further opinion, this time to be made public. Therein, the scope for collection was widened still: 'explicitly stating that the King could command contributions from his subjects and coerce the refractory. ${ }^{37}$ Again, Croke and Hutton

\footnotetext{
${ }^{30}$ See 'Specimen of the first Writ of Ship-money' in SR Gardiner (ed) Documents of the Puritan Revolution 1625-1660 (Oxford, Clarendon Press, 1889) 105.

${ }^{31}$ MD Gordon, 'The Collection of Ship-Money in the Reign of Charles I' (1910) 4 Transactions of the Royal Historical Society 141, 143.

${ }^{32}$ For the record, the danger spelled out in this writ was virtually identical to that of the first.

${ }^{33}$ Quoted in Richard L Noble 'Lions or Jackals? The Independence of the Judges in Rex v. Hampden' (1962) 14 Stanford Law Review 711, 715.

${ }^{34}$ Tanner (n 29) 77.

${ }^{35}$ DL Keir 'The Case of Ship-Money' (1936) 52 Law Quarterly Review 546, 555.

${ }^{36}$ Noble (n 33) 716.

${ }^{37}$ Keir (n 35) 555.
} 
disagreed. This time, however, it was urged 'that the lesser number must submit to the major, although they varied in opinion,' and the opinion did as if it was unanimous, published as the 'resolution of "all the judges of England". ${ }^{38}$ With the opinion of the judges (seemingly) behind them, the Crown felt confident that the legality of ship money could withstand judicial scrutiny, and brought proceedings against the politician and noted opponent of the King, John Hampden, for his refusal to pay. ${ }^{39}$

\section{III. 'A CONTROVERSY LIKE NO OTHER'}

The substitution of the king's judgement with that of Parliament was not original to Parker's famous response to the majority in Hampden. As with the majority opinion of Jones, for Croke the courtroom was an inappropriate forum for the resolution of such fundamental questions as the constitutional relationship between the monarch and his subjects. However, in stark contrast to Jones - who left 'divines' to such determinations - for Croke, the question was best resolved neither by divines nor by the court, but in 'a public Assembly of the whole State. ${ }^{40}$ This early attempt to locate a constitutive power - one which embraces radical disagreement about the very distribution of power within the state - in (an assembly of) the people met with the monarch's rebuke, and Croke duly obeyed Charles' demand for the case to be heard. It was, furthermore, a position upon which Croke stood alone. The language of the bench was, quite naturally, that of fundamental laws, of the ancient constitution, of the monarchic history and traditions of the English constitution, but by employing this language the law kept closed the emergence of subjects as citizens: of the people as an active rather than a passive political, legal, and constitutional force. Nevertheless, his opinion, albeit delivered by reason of obedience, was one which remained rooted to an idea of the people (at least as constituted in Parliament) as the Commonwealth's constituent power and legitimising authority. Having failed to replace the judgement of the court with that of the 'whole nation', Croke's opinion called for the no less revolutionary substitution of Parliament for the King as the repository of salus republicae. 'We have a pious King,' he said, 'and he will not [abuse his power, by declaring an emergency where none exists], but the law looks into the inconvenience. ${ }^{41}$ The law in other words must assume at least the possibility that the monarch (or rather, in his caution, some future monarch) may either abuse their power personally, or use it unnecessarily on the basis of misinformation. Safer, therefore, to trust 'the

\footnotetext{
${ }^{38}$ Noble (n 33) 716. It was alleged that in order to procure support for the King from all the judges Finch had used bribes and threats to secure their signatures: see WJ Jones, Politics and the Bench: The Judges and the Origins of the English Civil War (London, George Allen \& Unwin Ltd, 1971) 127.

${ }^{39} R v$ Hampden (1637) 3 State $\operatorname{Tr} 826$.

${ }^{40}$ Ibid at 146 per Croke.

${ }^{41} \mathrm{lbid}$
} 
judgement of Parliament', and neither the monarch nor their counsel, in the assessment of any such emergency. This proposition, rejected explicitly in the majority opinion of Finch, ${ }^{42}$ was doubted even by Croke's allies in the minority.

Throughout the 1630s, a decade of government without Parliament, the public's perception of the latter was somewhat mixed. To some, and in this we can include Croke, Parliament was a council comparable to the Roman Senate, in which the King:

...could hear advice important to him and to the realm. He could insure that his subjects understood his needs, demonstrate his concern for them by hearing their grievances, and avoid embarking on a course of action for which he would find it difficult to obtain their support. ${ }^{43}$

In Parliament, in other words, opinions could be exchanged, tested and formed, and, more than that, imparted to the king, influencing his own opinion. It was also variously seen as a supporter in war, a maker of laws and a granter of taxes. Yet, Cope has argued that in its absence 'few individuals expressed either regret...or desire that one be called. ${ }^{44}$ Thus it was the view of Parliament as 'a turbulent assembly where overzealous subjects poured out grievances and aspired to assume authority over matters which they did not understand and which belonged to the royal prerogative ${ }^{\prime 45}$ which found the strongest support amongst the judiciary in Hampden.

In the context of early Stuart England, where (cosmic or divine) order was revered, the charge of disorder made against Parliament, initiated by the Crown and reaffirmed by the majority of the judges in Hampden, was a potent one. In an instant, however, Parker turned those very claims back upon the judiciary, opening his Case of Shipmony with wonder at the 'strange contradiction' that existed 'amongst the pleaders, and dissent amongst the Judges, even in those laws which are most fundamental, that we are left in a more confused uncertainty of our highest privileges, and those customs which are most essential to Freedom than we were before. ${ }^{\prime 46}$

Parker's prescription was made with gusto; the publication of The Case of Shipmony, timed to coincide with the opening of the Long Parliament, stating with clarity and precision that:

\footnotetext{
$42 \mathrm{lbid}$ at 203 per Finch.

${ }^{43}$ Esther S Cope, 'Public Images of Parliament during Its Absence (1982) 7 Legislative Studies Quarterly 221, 226.

${ }^{44}$ Ibid 222.

45 lbid 225.

${ }^{46}$ Henry Parker, The Case of Shipmony Briefly Discoursed, According to the Grounds of Law, Policy, and Conscience, and Most Humbly presented to the Censure and Correction of the High Court of Parliament (London, 1640) 1-2.
} 
To remove...this uncertainty, which is the mother of all injustice, confusion, and public dissent, it is most requisite that [Parliament] (of which none ought to think dishonourably) would take these Arduis Regni, these weighty and dangerous and dangerous difficulties, into ferocious debate, and solemnly end that strife, which no other place of Judicature can so effectually extinguish. ${ }^{47}$

As Michael Mendle has said, the 'intellectual and political task of The Case of Shipmony...was to reestablish order amidst the confusion' engendered by the judgement. ${ }^{48}$ It was the near unanimous verdict of the judges in Hampden that the case was the most significant constitutional dispute to come before an English court. And yet, for Parker, the astonishing fact betrayed by their various opinions was that the 'greatest Sages of our Law ${ }^{49}$ had no firm idea of the constitutional fundamentals upon which the King's (undisputed) power to compel aid in times of emergency in fact, as well as in theory, was grounded. At times the judges argued upon grounds of natural law. That 'since the King is head, and bound to protect, therefore he must have wherewithal to protect.' Some argued from the prerogative, yet Parker was left unsure as to the exact nature of that prerogative: 'whether [it be the] Prerogative natural of all Kings, or the Prerogative legal of the Kings of England.' Some argued that 'by Law there is natural allegiance due to the King from the subject,' by which the monarch could not be denied the grant of aid; whilst others argued from the very opposite: that by law man had a right in his property, 'and it doth not stand with that property, that the King may demand of them without consent.' Finally, it was argued that the king's prerogative could not be used to create injustice, from the starting assumption 'that to levy money without consent is unjust. ${ }^{50}$ To rest the prerogative on such uncertain ground was, for Parker, '[t]o introduce...such a Prerogative...as destroys all other Law, and is incompatible with popular liberty. ${ }^{51}$ Echoing the contributions made by Peard, Seymor and St John in the debates of the Short Parliament, the decision to uphold Charles' policy on such a basis stripped the subject of more than his right to property. '[I]f we grant Ship money upon these grounds with Ship money we grant all besides. ${ }^{152}$ That is to say we grant to the King not only our property, but - in conceding to so broad a discretion - we surrender also our status as free subjects. ${ }^{53}$

\footnotetext{
47 Ibid 2.

${ }^{48}$ Michael Mendle, Henry Parker and the English Civil War (Cambridge, CUP, 1995) 35.

${ }^{49}$ Parker (n 46) 2.

50 Ibid 3-4.

51 lbid 2.

52 Ibid.

53 lbid 4.
} 
Thus where law is no longer made in co-ordination between prince and people - wherein each is capable of wooing the opinion of the other, or at least to modify one's own in light of it - but instead where the mere will of the King is law, where Rex is indivisibly lex, the people are no less miserable in their subjection to the king, as is the slave to his master. ${ }^{54}$ This, Parker observed, was precisely the danger which lurked in the majority's support for the charge of ship money:

...as sole judgement is here ascribed to the King, he may affirm dangers to be foreseen when he will, and of what nature he will: If he say only, Datum est nobis intelligi, ${ }^{55}$ as he does in his Writ...to his sole indisputable judgement it is left to lay charges as often and as great as he pleases. And by this means if he regard not his word more than his profit, he may in one year drain all the Kingdom of all its treasure, and leave us the most despicable slaves in the whole world. ${ }^{56}$

What concerned Parker was not merely the use by the King of his prerogative to violate the property rights of his subjects in this instance, rather it was the very existence of that prerogative, which might be exercised at any indeterminate time, by any indeterminate means, which left Charles' subjects in so dire a predicament. Parker, in Quentin Skinner's estimation, therefore became Parliament's 'most lucid and resourceful supporter, ${ }^{157}$ for his ability to articulate this condition of uncertainty: by which the people 'possess [no] such liberties, since the very existence of such prerogative powers reduces us to a level below that of free subjects. ${ }^{158}$ No person, this was to say, could reliably act upon their freedom because no person could be certain that the liberties that they enjoyed today would endure tomorrow. In this way, the very essence of virtue was at stake:

Those who live at the mercy of such rulers learn to curb the very qualities that need to be given freest rein if civic greatness is to be achieved. The alternative...is to learn from experience that under tyranny the possession of outstanding qualities is a 'capital crime'. With virtue effectively proscribed, we are condemned to living in a servile society in which flatterers and time-servers flourish unopposed. ${ }^{59}$

\footnotetext{
${ }^{54}$ Ibid 5.

55 'It is given us to be understood'.

${ }^{56}$ Parker (n 46) 11.

${ }^{57}$ Quentin Skinner, Visions of Politics, Volume II: Renaissance Virtues (Cambridge, Cambridge University Press, 2002) 293.

58 lbid 288.

59 lbid 290.
} 
It was amidst this uncertainty that Parker sought to establish an island of predictability and, with that, a forum for the expression of civic greatness in the institution of Parliament.

\section{PARLIAMENT'S PRIVADO}

More, then, than an acid analysis of the majority opinion in Hampden, Parker's Case of Shipmony would lay the key-stone for a full blown account of Parliamentary absolutism. For Parker, the divine constitution in which the king had sat as God's lieutenant on Earth had proven itself by the king's own actions to be inadequate:

Divines of late have been much to blame here in preaching one universal form of government, as necessary to all Nations [that being monarchic rule by divine right], and that not the moderate and equal neither, but such as ascribes all to Sovereignty, nothing at all to popular liberty. ${ }^{60}$

It was 'not sufficient,' he said, for Jones, in his majority opinion, to determine that Kings might lawfully raise money without the consent of their subjects, 'unless he first prove that such Prerogative be good and profitable for the people. ${ }^{61}$ It was, moreover, insufficient for the majority to hold that, in so proving, 'it is contrary to presumption of Law to suspect falsity in the King. ${ }^{162}$ In support of his counterproposition Parker offered examples which must have shocked his audience: that even England's 'best Kings, King Charles, King James, Queen Elizabeth...have done undue illegal things,' having been misinformed by their Ministers. ${ }^{63}$ Whilst at this stage Parker was either unwilling or unprepared to make the more explicitly republican argument that monarchs ought to give account before the people for the 'illegal things' done unto them, he nevertheless hinted as much in his stated refusal to 'condemn any Nation as unjust' who had, for the most part throughout Christendom, displaced the absolute monarch and 'given [themselves] to republics or to conditional and restrained forms of government. ${ }^{64}$

If it was just, in the last place, for the people to rise up against their monarch; if some have chosen republics, or other restrained governments, where once they had submitted to monarchy, then Parker must at this point in time have understood the further implication that in the political community itself was to be found the original (that which forms the shape of government) and the

\footnotetext{
${ }^{60}$ Parker (n 46) 8.

61 lbid 6.

62 Ibid 21.

$63 \mathrm{lbid}$

${ }^{64}$ Ibid 7-8.
} 
final (that which contests the shape of government) locus of political power. Parker did not, here, follow his arguments to the conclusion that monarchy had no place in the English constitution. However, his claim that by the constitution all Kings, good or bad, should act only and always in Parliament was no less revolutionary. Such a King, he advised, 'which is potent in Parliament, as good as any King may, is as it were so ensconced in the hearts of his subjects, that he is almost beyond the trains or aims of treason and rebellion at home, nay foreign hostility cannot pierce him, but through the sides of all his people. ${ }^{65}$ As Mendle has said, to give Parker's words their due 'is to come close to asserting Parliamentary control of executive power. ${ }^{166}$

That Parker attributed the 'undue' and 'illegal' acts committed even by virtuous monarchs to the 'misinformation' offered by their counsel speaks to two possible lines of criticism, each challenging the appropriateness of the monarch's right to act as the sole judge of the common good. On the one hand it is probable that Parker himself did not believe Charles to be one of England's 'best Kings,' as he had said, but that, aware of the consequences of making a direct claim for Charles's incompetence or, worse still, nefarious designs, Parker found it strategically advantageous to level those claims instead at the King's trusted advisors. ${ }^{67}$ In addition, however, is the underlying implication that such misinformation as did make its way to the King might itself have been symptomatic of the suffocation of virtue under subjugation; that the slide to 'slavish servility', to 'cowardice' and 'sloth', of which those Roman authorities such as Sallust and Tacitus had warned, could easily translate, in the minds of contemporary Englishmen, to those who had so ill-informed Charles throughout his reign. ${ }^{68}$ Discouraged from the heroic virtues of political action by their King, Englishmen could rely only on a small circle of 'cowards', 'time servers' and 'flatterers' to advise their monarch. No wonder, then, Parker's observation that 'it is more probable and natural, that evil may be expected from good Princes, than good from bad. ${ }^{69}$ Because the state suffers equally whether that 'evil' springs forth from the King's malice or from his ministers' bad (or slavish) advice, the law must, he said-contrary to the majority opinion in Hampden - allow the king's actions to be scrutinised. '[I]f we must presume well of our Princes,' he asked, 'to what purpose are Laws made. ${ }^{70}$ Parker's claim was not that Charles

\footnotetext{
${ }^{65}$ Ibid 38.

${ }^{66}$ Michael Mendle, 'The Ship Money Case, The Case of Shipmony, and the Development of Henry Parker's Parliamentary Absolutism' (1989) 32 The Historical Journal 513, 526.

${ }^{67}$ Mendle notes that as a 'pure, freestanding printed political tract [The Case of Shipmony] was not a natural mode of expression' at that time. Rather it stood out for '[taking] a current issue and [discussing] it in a way that led to practical prescription...as well as to a broader political vision' ((n M) 32-33).

${ }^{68}$ Skinner (n 57) 290.

${ }^{69}$ Parker (n 46) 21-22.

${ }^{70}$ Ibid 22.
} 
would falter, although the implication was there. '[I]t is enough,' was his point, 'that we all, and all that we have are at his discretion. ${ }^{71}$

If the King had shown by his actions the limits of the divine constitution, Parker was equally clear that the sovereignty of law, personified by the judges and expressed in their judicial opinions, was an incapable alternative. Laws are made; they are as rules; and, whilst they exist to limit the discretion of executive power, this could not manifest as the sovereignty of law. This was because laws are always subject to exception:

God dispenses with many of his Laws, rather than salus populi ${ }^{72}$ shall be endangered; and that iron-law, which we call necessity itself, is but subservient to this Law: for rather than a Nation shall perish, anything shall be held necessary, and legal by necessity... ${ }^{73}$

It was clear, to Parker, that the king was an unsatisfactory judge of so extraordinarily powerful a state of exception, because of his exposure to private interest and bad counsel. However, the judges fared no better - for it was they who (amongst others) provided that counsel. Insurrections, suggested Parker, served to warn Kings not to 'overstrain their Prerogatives too high.' He continued, however, that they served equally 'to warn all wise Princes...not to give ear to such Counsellors as some of our Judges are, who affirm the King's Prerogative to be in all points unalterable, and by consequence not depending upon Law at all. ${ }^{74}$ For Parker, the decision of the majority to uphold the taking of ship money without the consent of Parliament was worthy itself of punishment. Thus, closing his argument, he recommended that 'some dishonourable penalty may be imposed upon the Judges which ill advised the King herein, and the argued as Pleaders, not as Judges. ${ }^{175}$ The judges themselves had, in Parker's estimation, acted as a branch of the Crown and not as an impartial and fair arbiter between the King's prerogative and the subject's liberty. By placing the prerogative power beyond the reach of the court that power, in Parker's view, tended to the de facto destruction of all laws. 'If,' he said, 'a King should shut up the Courts of ordinary Justice, and prohibit all pleadings and proceedings between man and man, and refuse to authorize Judges for the determination of suits, he would be held to do a most

\footnotetext{
${ }^{71}$ Ibid.

72 That 'the health of the people is the supreme law'.

${ }^{73}$ Parker (n 46) 7.

74 lbid 9.

75 lbid 47.
} 
unkingly thing, ${ }^{176}$ and yet, the effect of the judges' slavish support for the King's policy - whose 'necessity has been answered, and disproved already'77 - was almost the same.

In Parliament, on the other hand, the case of necessity would be the subject of ferocious debate, demanding of the very virtues suffocated by subjection to monarchic rule: wisdom, sincerity, and greatness.

Wisdom, said Parker, could not be expected from the King nor from his few advisors, for 'all private single persons may deceive and be deceived.' It was inconceivable, however, that 'an inconsiderable number of Privados should see or know more than whole Kingdoms,' as, 'all cannot deceive one, nor one all.' In Parliament, however, was to be found a public forum in which the great controversies of the day were openly and freely debated from a multiplicity of perspectives that tended against duplicity. It was, then, 'a just law, that no private man must be wiser then Law publicly made.' 78 The very assembly, the public assembly, of the 'whole kingdom ', as it was put, had endowed the institution of Parliament with wisdom; such wisdom as the king, in the privacy of his counsel, could never achieve. The sincerity of Parliament's advice is attributed, by Parker, to the presence of God amongst the assembled, and yet remained at the same time inherent in the people. Blessed by God 'so their ends cannot bee so sinister,' the 'common body can effect nothing but the common good, because nothing else can be commodious for them. ${ }^{79}$ The contrast of course was with the king. Not only, contra Jones, could the king do wrong, all kings, great and tyrannous alike, had done wrong; their private interests, or those of their closest advisors bringing 'common calamity' to the nation. ${ }^{80}$ Parliament, on the other hand, could do no wrong to the kingdom because it was the kingdom. Any course other than the common good could therefore only be against its, and inextricably the public's, interests. ${ }^{81}$

By tapping into the wisdom and sincerity of Parliament the king would achieve true greatness; this because more than wisdom, more than sincerity, Parliament offered a public space into which heroic action could be seen and be remembered in the 'hearts of the people': hearts, Parker said, which beat with such force for the public welfare that any king 'potent in Parliament...is [put] almost beyond the [the fate] of treason and rebellion' which had befallen so many tyrants. ${ }^{82}$ Such hearts the king's few ministers simply could not carry, even if their counsel was both wise and sincere. For sure,

\footnotetext{
${ }^{76} \mathrm{Ibid}$.

77 Ibid 44.

78 Ibid 35.

79 Ibid 35-36.

80 Ibid 36.

${ }^{81}$ Robert Zaller, 'Henry Parker and the Regiment of True Government' (1991) 135 Proceedings of the American Philosophical Society 255, 258.

${ }^{82}$ Parker (n 46) 36.
} 
it was possible to argue that the advice given to the Crown regarding the need for and implementation of ship money was legally defensible. In the hearts of the people, however, the argument was lost: the sharp collapse of the policy that immediately followed the judgment was evidence itself that the view of Charles as an 'arbitrary' and 'absolute' monarch had formed in the minds of his subjects: ${ }^{83}$ 'no Tyranny is more abhorred,' said Parker, 'than that which has a controlling power over all Law, and knows no bounds but its own will. ${ }^{84}$

James I in word, and Charles I in deed, had established their accountability to no other authority than God himself by tracing the origins of their temporal office to divine sanction from heaven: to the divine right of kings to rule on Earth. For Parker to claim that the king must find greatness in Parliament, or risk bringing tumult upon his reign, required more than a challenge to the fiction of divine right, but the discovery of a new founding principle upon which the authority of that Parliament could rest. In The Case of Shipmony a case was tentatively made that it was by the people themselves that political power was conferred upon the king. From Charles' own maxim, that 'the peoples liberty strengthens the Kings prerogative, and the Kings prerogative is to maintain the peoples liberty ', Parker inferred not only that prerogative and liberty were compatible, but that the former, which exists purely for the sake of the latter, must be subordinate; that by nature 'more favour is due to the liberty of the subject, then to the Prerogative of the King, since the one is ordained only for the preservation of the other. ${ }^{185}$ As Zaller has said, this was more than the mere restoration of balance following constitutional rupture. Rather, 'it was a decisive alteration in the equation'; 86 a new form of government, it might be said, of world-historic importance. For sure James I had advised his heir that the king was ordained for his subjects, and not his subjects for the king. Contrary to the claims of divine right however, the question which followed was not 'what liberty the Kings absoluteness or prerogative may admit' but instead, 'must be, what prerogative the peoples good and profit will bear. ${ }^{187}$ In Parliament, it would seem, Parker had found the means by which the limits of the people's forbearance could be measured. Implicit was the message that the king had been created by the people, his prerogative for their welfare; that therefore the people, or a manifestation thereof, best knew the limits of both. What was implicit in The Case of Shipmony would soon be made explicit:Parker beginning his Observations of July $1642^{88}$ with the powerful assertion that:

\footnotetext{
${ }^{83}$ Glenn Burgess, The Politics of the Ancient Constitution: An Introduction to English Political Thought 1603-1642 (Pennsylvania, Pennsylvania State University Press, 1992) 202.

${ }^{84}$ Parker (n 46) 22.

${ }^{85}$ Ibid 4-5.

${ }^{86}$ Zaller (n 81) 257.

87 Parker (n 46) 5.

${ }^{88}$ Henry Parker, Observations upon some of his Majesties late Answers and Expresses (London, 1642).
} 
Power is originally inherent in the people, and it is nothing else but that might and vigour which such or such a society of men contains in itself, and when by such or such a Law of common consent and agreement it is derived into such and such hands. ${ }^{89}$

From the divine sanction of God to the constituent power of the people, the prescription which would become Parker's epitaph was that in Parliament's hands was salus republicae, that supreme law, safest, because Parliament itself was the people in whom political power naturally inhered.

However, if we revisit, for a moment, the story of Ship Money, we can see the emergence, if even for a fleeting moment, of an active, a real people, resisting the king and calling his authority into question. Moreover, it was this initial moment of local resistance which opened the space within which Parliament - most conspicuously through Parker - could re-invent the nation's constitutional foundation.

\section{THE PEOPLE OUT OF DOORS: SHIP MONEY RE-VISITED}

If the extension of Ship Money to the inland counties caused contemporaneous controversy, its value remains contested even to this day. Kevin Sharpe has called Ship Money the 'great success story' of personal rule. 'It is significant,' he argues, 'that when the writ was extended from the maritime counties to the country at large, the point at which the legality [of the policy] might have been questioned, only $2 \frac{1}{2}$ per cent of the sum requested failed to come in, and the amount raised, $f 194,864$, was never exceeded. ${ }^{90}$ On the other hand, Lamar Hill ascribes 'failure to the six years of Ship Money collection which ended in 1640.' Despite the immediate success of the policy - the per annum average of $£ 107,000$ (even allowing for the virtual non-collection of the final year) amounted to the highest peace-time direct tax receipt ever recorded ' - for Hill the policy 'failed utterly in the long run and was a major divisive element in the build up to civil war. ${ }^{91}$ Certainly, the effect of Hampden on the success of collection suggested at best a temporary and limited victory for the Crown. Despite the 7-5 majority decision in the King's favour, the narrowness of that victory, and the articulation of strong dissenting opinions, preyed on the suspicions of the people at large that the charge being asked of them was illegal. As Cromartie said, '[f]rom a practical political perspective, the only thing that mattered was

\footnotetext{
${ }^{89}$ Parker (n 88) 1.

${ }^{90}$ Kevin Sharpe, Politics and Ideas in Early Stuart England: Essays and Studies (London \& New York, Pinter Publishers, 1989) 115.

${ }^{91}$ LM Hill, 'County Government in Caroline England, 1625-1640' in Conrad Russell (ed), The Origins of the English Civil War (Basingstoke, Palgrave Macmillan, 1973) 83.
} 
that virtually all England [already] believed that the payments demanded were indefensible. ${ }^{92}$ Thus, in the months between the hearing of the arguments and the delivery of the judgment a number of people opted to withhold payment in anticipation of the policy being held to be illegal. If large numbers continued to pay, and this (in the very short term at least) they did, their doing so seemed to be an act of compliance rather than an act in support of the Crown's authority. How else to explain that not defeat but a narrow victory for the Crown saw 'by 1638 a falling off and by 1639 only a fraction' of successful collection $?^{93}$ The judges, it was said, had acted 'upon such grounds and reasons as every stander-by was able to swear was not law, ${ }^{94}$ and this, coupled with the quick and influential spread of the minority verdicts, soon precipitated the collapse of the entire policy. As early as May in 1638 it was noted that '[t]he King's moneys come in a great deal more slowly than they did in former years, and that to a very considerable sum. ${ }^{95}$ Reporting on the difficulties of collection, Clarendon was clear in his opinion that the spread of the judgements had the paradoxical effect of strengthening Charles's subjects in their resolve to resist collection, ${ }^{96}$ as a 'considerable' deficit shortly gave way to 'extraordinary public [and on occasion violent] hostility,' and a collection of almost nil. ${ }^{97}$ As Cressy concluded, 'Ship money became uncollectable, even before Parliament declared it illegal. ${ }^{98}$ In spite of, indeed following Clarendon it is surer to say because of, the Crown's victory in Hampden, the very prerogative of the Crown to act as it saw fit in the face of a perceived threat to the state seemed to lose its binding force. That this was no petulant strike against authority, no individual objection by men of means to the confiscation of their property, but a resistance which took place in that grey area between the letter and the spirit of the constitution, a resistance to law in the name of legality, is supported by the fact that the occurrence of disobedience was sporadic and rare, until it had become clear that the legal process had failed in its rights protecting function. What is more, it was the strength of the dissenting opinions which had emboldened that resistance and 'had increased the difficulties of collection. ${ }^{99}$

This moment of resistance is both significant, and largely ignored, in constitutional interpretations of this period, which focus on the Parliament's invocation of the people in the abstract - the mere substitute for a king who, before his Fall, had reigned over the whole nation. So, Loughlin

\footnotetext{
${ }^{92}$ Alan Cromartie, The Constitutionalist Revolution: An Essay on the History of England, 1450-1642 (Cambridge, Cambridge University Press, 2006) 239.

${ }^{93}$ Jones (n 38) 128

${ }^{94}$ Clarendon's History of the Rebellion, quoted in Tanner (n 29) 78.

${ }^{95}$ Letter of Laud to Wentworth, quoted in Tanner ibid 79.

${ }^{96}$ Jones (n 38) ch 5.

${ }^{97}$ Conrad Russell, 'Parliament and the King's Finances' in Russell (ed) (n 91) 109.

${ }^{98}$ David Cressy, England On Edge: Crisis and Revolution 1640-1642 (Oxford, Oxford University Press, 2007) 355.

99 Jones (n 38) 128.
} 
says that 'the conviction that governmental authority was rooted in the opinion of the people' was employed 'to strengthen the Parliamentary case'; whilst Morgan takes it even further, calling the sovereignty of the people 'an instrument by which representatives raised themselves to the maximum distance above the particular set of people who chose them,' shedding their specific local connections in doing so. ${ }^{100}$ Yet, before those claims could be made, it was in the (as we look back) somewhat obscured realm of local politics that the resistance to the Crown had taken shape. This may have reached its apogee in a national institution, when John Hampden's case was heard by the Court of Exchequer, but it had begun in the counties, where the extension of Ship Money had sharpened even the most introspective localities to the emergence of an urgent threat to their liberties. ${ }^{101}$ Indeed, in the county of Kent, feeling the pinch of the levy more than most, ${ }^{102}$ leading families had come together in their objection, circulating amongst themselves the preparation of a Book of Arguments against the policy, which centred on their perception of its illegality. ${ }^{103}$ Thus, amongst their number, the Historian and (later) Member of the Short Parliament, Sir Roger Twysden, having first accepted the necessity of the levy, became, after due study of the precedents, convinced that it could not be defended in law; their concerns filtering down to the townsfolk and farmers who 'bitterly complained' of the tax's iniquity. ${ }^{104}$ So, when Hampden - himself born of one of the leading families in his own home county of Buckinghamshire - was brought before the court for his steadfast refusal to give up that which had been demanded of him, he was more than the representative of a people in the abstract threatened by the King's recklessness, but of the people as a working reality in their various counties, sharing - in the exchange of their grievances - something of a unifying cause. To create a Book of Arguments against the policy, to challenge the legitimacy of the King's writ in the court room, to withhold payment, actively to resist those sheriffs sent for collection: each of these acts opened and maintained a space - between law's letter and law's spirit - into which the people could emerge in a spirit of deed and of action. More still, this space simply could not co-exist with a conception of monarchy which held the king accountable to no human authority. As such it demanded both the knocking down of government as Stuart Royalists had known (or at least, had told) it, and the building up of a new form of government, capable of harnessing that spirit.

\footnotetext{
${ }^{100}$ Edmund S Morgan, Inventing the People: The Rise of Popular Sovereignty in England and America (New York, Norton, 1988) 50; Martin Loughlin, 'Constituent Power Subverted: From English Constitutional Argument to British Constitutional Practice' in Martin Loughlin and Neil Walker (eds), The Paradox of Constitutionalism: Constituent Power and Constitutional Form (Oxford, Oxford University Press, 2007) 33-35.

${ }^{101}$ See Anthony Fletcher, The Outbreak of the English Civil War (London, Edward Arnold, 1981) xxvi. 102 Gordon (n 31).

${ }^{103}$ Alan Everitt, The Community of Kent and the Great Rebellion 1640-60 (Leicester, Leicester University Press, 1966) 63-64. 104 Ibid 64.
} 


\section{JUS POPULI AND THE LOST TREASURE}

It was not until he was freed from his obligations to Parliament that Parker himself followed the logic of the claim that power inhered in the people to his most radical conclusion: that sovereignty itself, and not merely the divine variety, was unpolitical. In one of his final, but less explored, political tracts, (the anonymously published) Jus Populi, Parker set out to dispel the royalist claim that political power was at all hierarchical in nature. Finding agreement with his opponents that domination inheres in private relationships - that the father properly is possessed of a natural authority over his son, ${ }^{105}$ that the husband is naturally possessed of a contractual authority over his wife ${ }^{106}$ - the boldness of Jus Populi lay in detaching political power and public interests from any analogy with private power and personal interests. For one, whilst the son, wife and household stood to benefit from their submission (and I will leave for elsewhere a critique of domination in private relationships), ${ }^{107}$ the condition of 'servitude' created by 'absolute, arbitrary' government 'professes no justice in itself.' ${ }^{108}$ Indeed, he said to the contrary that such rule encourages injustice: 'arbitrary government does not only rob slaves of that natural interest which they have in themselves, and states of their public interests...but it is often a very strong incentive to cause an abuse of that usurped interest. ${ }^{109}$ For another, government itself (arbitrary or otherwise; monarchic or democratic) was created in the exercise of (what then must be a political) freedom, and neither by nature (father/son) nor necessity (husband/wife). Thus, he said: 'I conceive that freedom being in itself good, and acceptable to Nature, was preferred before government, which was also good,' with the consequence that prior to any government was the freedom to create that government. If government was not to 'abuse the usurped interests' of its citizens, it was important for Parker that under the weight of government 'man be left free and not abridged of his own consent [and note the positive/political connotation of freedom as consent here, surely more demanding than, say, (negative/private) liberty] or forced by any Law of God to depart from his freedom. ${ }^{110}$ For Parker, arbitrary or absolute or sovereign authority obscured the reality that political power inhered in the community of (plural) men. Following this, when Parker declared 'horrid, unnatural, and altogether...damnable' those who denounced resistance - 'for hereby it is

\footnotetext{
105 Henry Parker, Jus Populi (London, 1644) 33-34.

106 Ibid 35-36.

${ }^{107}$ Note, however, that for Parker the powers of father over son, husband over wife, whilst ordered hierarchically did not amount to 'jurisdiction' or to 'coercive' control: disputes therein were properly to be settled not by the father/husband's will but by 'an impartial judicator' or other 'public authority' (Ibid 32).

108 Ibid 36.

109 lbid 38.

110 Ibid 5-6.
} 
plainly averred that either government was erected for subversive ends, or else that general subversion may conduce malevolent ends' ${ }^{111}$ - it would seem that his reassertion of that reality in an act of dissent against constituted power was the surest way to rein in domination.

Here, however, is the rub: and the trick which has remained with us since. What Parker said in Jus Populi was undoubtedly radical. Yet the force of the argument was lost with the immediate proviso that 'Parliament is...nothing else, but the very people itself; 'that the two [Parliament and people] ought not, 'in honour, in majesty, in commission...to be divided, or accounted different.'112 Put differently, having proclaimed that government must not abridge the peoples' consent, lest it be encouraged to nefarious ends, Parker immediately exchanged the real world for an imaginary one: with the fiction that Parliament was the people, that the consent of Parliament was indivisible with and gave expression to the consent of the people. The importance of this is not to be underestimated. If the people consent to government, they can legitimately confront it in an act of dissent. If the people created Parliament in an act of consent, then the people might legitimately dissent where Parliament abuses its power. However, to say that Parliament was the people was to deny any prior constitutive act, and therefore any right to revoke or to re-order that act. That there was no public realm outwith Parliament's walls, no space of appearance in which opinions could be exchanged and formed - let alone the sort of resistance encouraged and praised when directed against the king - was firmly put in one anonymously authored pamphlet: '[Parliament's] judgement is our judgement, and they that oppose the judgement of Parliament oppose their own judgement. ${ }^{113}$ Thus, for Parker, there was nothing 'horrid, unnatural, and altogether...damnable' about advocating non-resistance to Parliament: indeed, he said, 'there can be nothing... which can be more perfidious and more pernicious in the people,' than resisting the acts of that institution. ${ }^{114}$ Another of Parliament's most prominent spokesmen, Charles Herle, was even more clear:

A...question begged [by the Royalist, Henry Ferne] is that in case the king and Parliament should neither discharge their trusts, the people might rise and make resistance to them both, a position which no man I know maintains. The Parliament is the people's own consent, which once passed they cannot revoke...the people have reserved no right in themselves from themselves in Parliament. ${ }^{115}$

\footnotetext{
111 Ibid 56.

112 Ibid 18.

${ }^{113}$ Anon, Plain Dealing With England (London, 1643) 2.

${ }_{114}$ Parker (n 88) 16.

${ }^{115}$ Charles Herle, A Fuller Answer to a Treatise Written by Dr Ferne (London, 1642).
} 
Having set out in Jus Populi to demonstrate that there was 'no sufficient rule, precedent, or authority, for arbitrary power,' indeed, having brilliantly done so, Parker immediately lay the foundations for the most arbitrary power of all, imagining a world in which others simply did not exist: Parliament was the people; there were no others. Parliament, in the most royalist of language, could 'do no wrong'. ${ }^{116}$

\section{CONCLUSION}

The story of ship money captures the legacy of the era: a period when, as Loughlin has said, 'a "constituting power" located in "the people" [first emerged] not simply as a rhetorical symbol but as an active force emerges for the first time, ${ }^{\prime 11}$ only to be repressed by those 'seeking to manage the unfolding English revolution'. ${ }^{118}$ This paradox is the fault line upon which the political constitution rests: the realisation by the Parliament men that there was no greater threat to the stability of the new order that they sought to establish than the revolutionary spirit harnessed by them in order to bring it into being, caused the question of constituent power - caused the question of what it is that is political about the political constitution - to be obscured. To escape this paradox let us return to where we started - with Marx, and with what Ewing has described as being perhaps the purest form of political constitutionalism. ${ }^{119}$

The constitutional preconditions established by Marx in The Civil War in France are grounded in two principles that - as we have seen - are incompatible with the construction of the political constitution on the 'bedrock' ${ }^{120}$ of Parliamentary supremacy. The first is that the people, according to Marx, register - constitutionally speaking - as a working reality and neither merely as a latent power ('[i]nstead of deciding once in three or six years which member of the ruling class was to misrepresent the people in Parliament,' Marx said, 'universal suffrage was to serve the people, constituted in Communes' $)^{121}$ nor, as in Parker's defence of Parliament, as a foundational myth. The second - and the key to understanding Marx's late writing on politics - is the turn to political organisation in spontaneous form. What Marx came to realise - and what, in the end, has drawn Ewing so tantalisingly towards this work - is that to contain politics (as accounts predicated on Parliamentary sovereignty do and indeed must) within a unitary and particular institutional form is to undermine the activity and in so doing to undermine the power - of politics itself. It is no wonder then that Ewing - a labour lawyer for whom political action in alternative spaces such as within the trades union movement

\footnotetext{
${ }^{116}$ John Marsh, An Argument or Debate in Law (London, 1642) 15.

117 Loughlin (n 23) 28.

118 Ibid 47.

${ }^{119}$ Or, so he said in the email exchange that inspired this chapter!

120 Jackson v Attorney General [2005] UKHL 56 at [9] per Lord Bingham.

${ }^{121} \operatorname{Marx}(\mathrm{n} 13) 25$.
} 
carries its own justification - has come to see the turn from power (to constitute political spaces anew) to accountability (within the already existing constitutional apparatus) as being little more than 'an indulgence and a distraction. ${ }^{122}$

What Marx saw in the Paris Commune was a new form of government that had emerged in reaction to, and in so doing that had unsettled, long standing assumptions both about the constitution of power and about the ends to which that power ought to be directed. A highly democratic form of government, the Commune was:

...formed of the municipal councillors, chosen by universal suffrage in the various wards of the town, responsible and revocable at short terms. The majority of its members were naturally working men, or acknowledged representatives of the working class. The Commune was to be a working, not a parliamentary body, executive and legislative at the same time. Instead of continuing to be the agent of the Central Government, the police was at once stripped of its political attributes, and turned into the responsible, and at all times revocable, agent of the Commune. So were the officials of all other branches of the administration. From the members of the Commune downwards, the public service had to be done at workman's wage. The vested interests and the representation allowances of the high dignitaries of state disappeared along with the high dignitaries themselves. Public functions ceased to be the private property of the tools of the Central Government. Not only municipal administration, but the whole initiative hitherto exercised by the state was laid into the hands of the Commune. ${ }^{123}$

For sure, Marx was alert to what he saw as being the failings of the Commune, most significantly its 'good nature' in avoiding a more direct conflict with a bourgeoisie who then in turn would crush it. Overwhelmingly, however, he was inspired by what it had achieved during its short life-span: the abolition of conscription; the separation of church and state, measures (albeit short of enfranchisement) for the betterment of women; the abolition of night work for bakers; the development of plans to re-open factories under the control of labour, and more besides. ${ }^{124}$ But - and this is the point - the Commune, for Marx, marked a 'new point of departure of world-historic

\footnotetext{
${ }^{122}$ Ewing (n 3) 350. Indeed, it is a curious omission that political constitutionalists have had a great deal to say about the protection of rights under the Human Rights Act 1998 and the balance between judicial power and the central executive/legislature but have had almost nothing to say about the creation of alternative, and sometimes rival, sites of political power in the devolved legislatures or in local government and about the dynamics that drive their relations with the centre. ${ }^{123} \operatorname{Marx}(\mathrm{n} 13) 25$.

${ }^{124}$ For commentary see Paul D'Amato, 'The Paris Commune' in The Socialist Worker (December 10 2002) online at https://socialistworker.org/2002-2/433/433 10 ParisCommune.php (accessed 14/05/19) and Paul Dorn, 'Two Months of Red Spendor: The Paris Commune and Marx' Theory of Revolution' online at http://www.runmuki.com/paul/writing/marx.html (accessed 14/05/19).
} 
importance ${ }^{125}$ not only because of what it was and what it had achieved but also because of what it represented: the discovery of a 'a working class government, the product of the struggle of the producing against the appropriating class, the political form at last discovered under which to work out the economical emancipation of labour., ${ }^{126}$

So where does this leave us? '[T]he polis properly speaking,' wrote Hannah Arendt, a critic of Marx who nevertheless shared his fascination with politics in this spontaneous and communal form, 'is not the city-state in its physical location; it is the organization of the people [wherever] it arises out of acting and speaking together. ${ }^{127}$ Political institutions, as Marx came laterally to recognise, might favour the creation of political power, but they are not a necessary precondition for its emergence. Political action, wherever it arises, however it registers, carries its own legitimacy and is not contingent upon constitutional form. Indeed, the reverse is true: to take seriously what is political about the political constitution is to expose Parker's work of fiction, that Parliament is the people and therefore can do no wrong, and instead to recognise that constitutional form is always contingent upon political power. That constitutional form, in other words, is itself the legitimate subject of radical disagreement.

${ }^{125}$ Karl Marx in correspondence with Ludwig Kugelmann, April 17 1871, reproduced in Marx-Engels Correspondence (New York, International Publishers, 1968), available online at https://www.marxists.org/archive/marx/works/1871/letters/71 04 17.htm (accessed 18/09/19). ${ }^{126} \operatorname{Marx}(\mathrm{n} 13) 27$.

${ }^{127}$ Hannah Arendt, The Human Condition (Chicago, University of Chicago Press, 1958) 198 [emphasis added]. 